\title{
Effect of Cold Plasma Treatment of Seeds on Quality of Seed Crop of Okra
}

\author{
Ravinder Kumar ${ }^{1 *}$, Ashok K. Thakur ${ }^{1}$, Amit Vikram², A. Vaid ${ }^{3}$ and R. Rane ${ }^{3}$ \\ ${ }^{1}$ Dept. of Seed Science and Technology, ${ }^{2}$ Dept. of Vegetable Science, Dr. Y. S. Parmar University of Horticulture and Forestry, \\ Solan, Himachal Pradesh (173 230), India \\ ${ }^{3}$ FCIPT, Institute for Plasma Research, Gandhinagar, Gujarat (382 044), India
}

\section{Corresponding Author}

Ravinder Kumar

e-mail: ravisehrawat.hau@gmail.com

\author{
Article History \\ Article ID: IJEP0299 \\ Received in 02 ${ }^{\text {nd }}$ April, 2019 \\ Received in revised form $10^{\text {th }}$ May, 2019 \\ Accepted in final form $22^{\text {nd }}$ May, 2019
}

\begin{abstract}
The effect of cold plasma treatment of seeds on quality of seed crop of okra [Abelmoschus esculentus (L.) cultivar P-8] was studied at Department of Seed Science and Technology, Dr Y.S. Parmar University of Horticulture and Forestry, Solan, Himachal Pradesh. The experiment comprising of seeds of two different age viz., 'A1' (One year old seed) and 'A2' (Two year old seed) and seven plasma treatments of seed viz., 'P1' (Only vaccum, no plasma treatment), 'P2' (3 minute), 'P3' (6 minute), 'P4' (9 minute), 'P5' (12 minute), 'P6' (15 minute) an 'P7' (Control without treatment). The seeds with different combination of treatments were evaluated for different quality parameters studied in laboratory. It was found that crop raised from one year old seeds resulted in higher germination percentage (92.39 \%) in comparison with crop raised from two year old seeds ( $86.29 \%$ ) and the seed treated with treatment ' $\mathrm{P} 5$ ' shows highest germination percentage i.e. $91.75 \%$. This may be due to higher thousand seed weight resulted in bolder seed and have sufficient food reserve, obtaining good quality fruits which resulted in higher germination percentage. Similarly other characters like speed of germination, seedling length, seedling dry weight, SVI-I and SVI-II were found to be maximum $(40.48,26.90 \mathrm{~cm}, 23.06 \mathrm{mg}, 2486.16$ and 2138.61 , respectively) in one year old seeds and minimum $(35.09,26.01 \mathrm{~cm}, 21.89 \mathrm{mg}, 2244.96$ and 1890.79 , respectively) in two year old seed. The reduction in seed quality parameters could be attributed to different in one year and two year old seed is due to ageing. Whereas in all the plasma treatments 'P5' shows highest speed of germination, seedling length, seedling dry weight, SVI-I and SVI-II. These results indicated that cold plasma treatment might promote the growth and modify the speed of germination.
\end{abstract}

Keywords: Okra, plasma treatment, exposure time, seed quality

\section{Introduction}

Okra (Abelmoschus esculentus L. Moench) of the family Malvaceae is one of the most popular vegetables in India. Its association with the local food in the different regions of the country created a great stable demand for it. It can be consumed after cooked as green pods and it is also used after dehydration (dried) and grinding as powder. The fresh fruit is a good source of vitamins, minerals and plant protein (Eke et al., 2012). Schippers (2000) stated that okra contains about $20 \%$ edible oil and protein, while its mucilage is utilized for medicinal purposes. The mature stem contains crude fibre which is used in paper industries and for making ropes (Schippers, 2000). Okra's flower can be very attractive and sometimes used in decorating the room (Schippers, 2000). Okra is cultivated under rainfed and in irrigated areas on a wide range of soils (Tiamiyu et al., 2012). The production is seriously affected by the use of low yielding, sub-optimal and inappropriate manure doses as well as late sowing date (Tiamiyu et al., 2012); Kol et al., 2012; Ayoub and Afrah, 2014).
Thick walls in some okra seeds delay germination. The seeds coats are often hard and the embryo can be slow to develop during germination. Consequently, treatments to seed coats which overcome hard seededness are generally required for germination.

There are different seed enhancement technologies like coating, pelleting, priming etc which increases the moisture content of the seed during treatment. Here, a dry seed treatment i.e. plasma treatment is employed to increase the seed coat permeability without increasing the moisture content of seed. The method of Plasma seed treatment is a physico-chemical method which has potential to improve germination yields and kill fungal spores carried on seed coats (Griesser et al., 2011). Cold plasma seed treatment is a modern eco-agricultural high technique that could increase crop yields (Jiafeng et al., 2014). A positive effect of low temperature plasma treatment on germination of various agricultural crops has been found (Sera et al., 2003). Today, plasma is used for varieties of industrial applications ranging 
from arc welding, metal hardening, nuclear fusion, creation of nano structure, functional polymer coating and change in surface hyrdrophilicity (Filatova et al., 2010). Hence, effect of cold plasma treatment on growth and yield characters of okra seeds was studied.

\section{Materials and Methods}

Seeds of okra [Abelmoschus esculentus (L.)Moench] cultivar P-8 were obtained from Dr. Y. S. Parmar University of Horticulture and Forestry, Solan, Himachal Pradesh, India and were exposed to cold plasma treatment under the following parameters: Glow Discharge plasma of oxygen gas was used at a base pressure of $0.05 \mathrm{~m}$ bar, operating pressure 0 f 0.2 $\mathrm{m}$ bar, voltage of $500 \mathrm{~V}$, current of $0.2 \mathrm{~A}$ and power of 100 $W$ for treatment durations of $0,3,6,9,12$ and 15 minutes. The plasma treatment was done at FCIPT (Facilitation Centre for Industrial Plasma Technologies), Institute for Plasma Research, Gandhinagar, Gujarat, India (An Institute under Department of Atomic Energy, GOI). The field experiment was conducted during July, 2014-15 at Agricultural Research Farm, Dr Y. S. Parmar university of Horticulture and Forestry, Solan, Himachal Pradesh, India in Randomized Block Design (Factorial) with seven treatments replicated four times in each. The farm is located at an altitude of 1183 meters above mean sea level with latitude of $30.51^{\circ} \mathrm{N}$ and longitude of $77.09^{\circ} \mathrm{E}$ the mid-hill zone of Himachal Pradesh, India observed with GARMIN'S GPS 12 Personal Navigator. During the crop season (July- October), the maximum average temperature $\left(23.7^{\circ} \mathrm{C}\right)$ was recorded in the month of August, 2014 and lowest average temperature in October, $2014\left(18^{\circ} \mathrm{C}\right)$; the average rainfall was maximum $(361 \mathrm{~mm})$ in July month and lowest $(15.7 \mathrm{~mm})$ in October and the average relative humidity was maximum (76\%) in July and lowest in October (60\%).

The seeds of okra were sown as per the treatments in a plot having size of $2.0 \times 2.4 \mathrm{~m}^{2}$ i.e. $4.8 \mathrm{~m}^{2}$. FYM and fertilizers were applied as per package of practices for vegetable crops, Directorate of Extension Education, Dr. Y. S. Parmar University of Horticulture and Forestry, Nauni, Solan (HP) (FYM @ 100 quintal per ha, CAN @ 300 kg ha-1, SSP @ 315 kg ha-1 and MOP @ 90 kg ha-1). The seeds harvested from the crop were tested for various quality parameters as per the methods described below:

\subsection{Germination (\%)}

Germination percentage was estimated according to standard germination procedure (ISTA, 1985). This was carried out by using between paper method in the seed germinator at $25^{\circ} \mathrm{C}$. The germination was counted on 21 day after sowing (DAS). Germination percentage was calculated using the formula:

Germination (\%)=(Number of normal seedlings/ Total number of seeds used) $\times 100$

\subsection{Speed of germination}

Speed of germination was calculated based on the formula of Maguire (1962)
Speed of germination $=\left(X_{1} / Y_{1}+\left(X_{1}-X_{2}\right) / Y_{1}+\ldots .+X_{n}-X_{n-1} / Y n\right.$

Where; $X_{1}, X_{2}$ and $X_{n}$ are number of seeds germinated on first , second and $n^{\text {th }}$ day, respectively and $Y_{1}, Y_{2}$ and $Y_{n}$ are number of days from sowing to first, second and $\mathrm{n}^{\text {th }}$ count respectively. Speed of germination is measured by top of paper method.

\subsection{Seedling length $(\mathrm{cm})$}

The length of seedlings was measured on 10th day of its germination. Ten normal seedlings selected at random from between paper method were used to work out the seedling length. Total seedling length was worked out by taking the total length of seedlings form the tip of the primary leaf to the tip of primary root with the help of scale and expressing the mean value in centimetre.

\subsection{Seedling dry weight ( $\mathrm{mg}$ )}

Ten seedlings selected for measuring seedling length were used to work out seedling dry weight. Seedlings were kept in oven at $80^{\circ} \mathrm{C}$ for 48 hours and weights were measured then mean value was expressed in milligrams.

\subsection{Seed vigour index-I}

Seedling vigour index-I was calculated as per the formula given by Abdul-Baki and Anderson (1973).

SVI-I = Germination $(\%) \times$ Seedling length $(\mathrm{cm})$

\subsection{Seed Vigour index-II}

Seedling vigour index-II was calculated as per the formula given by Abdul-Baki and Anderson (1973).

SVI- II=Germination (\%) $\times$ Seedling dry weight $(\mathrm{mg})$

\section{Results and Discussion}

\subsection{Germination}

The data presented in Table 1 indicated that the germination of okra seed exposed to plasma treatments was significantly higher in one year old seed $(92.39 \%)$ than that of two year old seed (86.29\%). This may be due to higher thousand seed weight resulted in bolder seed and have sufficient food reserve, obtaining good quality fruits which resulted in higher germination percentage. Increase in germination due to plasma treatments were reported in spring wheat, maize, oat and barley (Dubinov et al., 2000). The higher germination in one year old seed as compared to two year old seeds is due to age of seeds because loss of germination ability depends upon the time span as also been reported (Dell 1987). Seed treated with plasma significantly contributes to germination of Chenopodium album (Sera et al., 2012). The increase in germination may be due to the reason that plasma treatment removes effectively the very thin lipid layer that makes seeds water repellent, and probably reduces the length of biopolymer chain that makes up the seed coat, thus enabling better water uptake through seed coat and improves germination.

\subsection{Speed of germination}

The speed of germination of okra seed was significantly higher 
Table 1: Effect of seed age and plasma treatment on germination and speed of germination obtained from treated seeds in okra

\begin{tabular}{|c|c|c|c|c|c|c|}
\hline \multirow{2}{*}{$\begin{array}{l}\text { Plasma treatment } \\
\text { durations } \\
\text { (P) }\end{array}$} & \multicolumn{3}{|c|}{ Germination (\%) } & \multicolumn{3}{|c|}{ Speed of germination } \\
\hline & $\begin{array}{c}\text { One year seed } \\
\left(A_{1}\right)\end{array}$ & $\begin{array}{c}\text { Two year seed } \\
\left(\mathrm{A}_{2}\right)\end{array}$ & Mean $(P)$ & $\begin{array}{c}\text { One year seed } \\
\left(A_{1}\right)\end{array}$ & $\begin{array}{c}\text { Two year seed } \\
\left(\mathrm{A}_{2}\right)\end{array}$ & Mean (P) \\
\hline Vacuum & $90.75(90.57)$ & $84.00(9.21)$ & 87.35 (9.39) & 38.87 & 32.44 & $35.66^{\mathrm{ab}}$ \\
\hline 3 minutes & $91.50(9.61)$ & $85.00(9.27)$ & $88.25(9.44)$ & 39.15 & 34.45 & $36.80^{a b c}$ \\
\hline 6 minutes & $92.25(9.65)$ & $87.50(9.40)$ & $89.87(9.53)$ & 40.64 & 36.83 & $38.74^{\mathrm{bcd}}$ \\
\hline 9 minutes & $93.50(9.72)$ & $88.50(9.45)$ & $91.00(9.58)$ & 41.67 & 37.71 & $39.69^{\text {cd }}$ \\
\hline 12 minutes & 94.00 (9.74) & $89.50(9.51)$ & $91.75(9.62)$ & 42.31 & 38.71 & $40.52^{d}$ \\
\hline 15 minutes & $93.75(9.73)$ & $86.00(9.32)$ & $89.88(9.52)$ & 41.95 & 33.29 & $37.63^{\mathrm{abcd}}$ \\
\hline Control (untreated) & $91.00(9.59)$ & 83.50 (9.19) & $87.25(9.39)$ & 38.78 & 32.22 & $35.51^{\mathrm{a}}$ \\
\hline Mean $(A)$ & $92.39^{A}(9.66)$ & $86.29^{B}(9.34)$ & & $40.48^{A}$ & $35.09^{B}$ & \\
\hline \multirow[t]{3}{*}{$\mathrm{CD}(p=0.05)$} & (A) & 0.11 & & 1.71 & & \\
\hline & $(\mathrm{P})$ & NS & & 3.20 & & \\
\hline & $(\mathrm{AxP})$ & NS & & NS & & \\
\hline
\end{tabular}

in one year old seed (40.48) than that of two year old seed (35.09) is observed (Table 1).

Significant influenced in speed of germination as affected by exposure time of plasma to the seed. Higher speed of germination was, however, observed in the seed exposed to plasma for 12 minutes (40.52), which was at par with 9 minutes (39.69), 6 minutes (38.74) and 15 minutes (37.63) treatment. The seed which was kept under vacuum and not exposed to plasma showed significantly lower speed of germination (35.66) compared to plasma treated seeds. The lowest speed of germination (35.51) was recorded in control seed where no treatment was given. This may be due to the changes of the wetting properties of seed and seed coat, due to oxidation of their surface which leads to faster germination as earlier reported (Bormashenko et al., 2012). Plasma might improve the wettability of seeds and eventually influence the germination speed in wheat (Jiafeng et al., 2014).

Non-significant interaction effects due to age of seed and plasma exposure time were observed for speed of germination.

\subsection{Seedling length}

Data pertaining to seedling length, revealed significant variations due to the treatments given in these studies as presented in Table 2. Seedling length was significantly higher in one year old seed $(26.90 \mathrm{~cm})$ than that of two year old

Table 2: Effect of seed age and plasma treatment on seed seedling length and seedling dry weight obtained from treated seeds in okra

\begin{tabular}{|c|c|c|c|c|c|c|}
\hline \multirow{2}{*}{$\begin{array}{l}\text { Plasma treatment } \\
\text { durations }(\mathrm{P})\end{array}$} & \multicolumn{3}{|c|}{ Seedling length $(\mathrm{cm})$} & \multicolumn{3}{|c|}{ Seedling dry weight (mg) } \\
\hline & $\begin{array}{c}\text { One year seed } \\
\left(A_{1}\right)\end{array}$ & $\begin{array}{c}\text { Two year seed } \\
\left(\mathrm{A}_{2}\right)\end{array}$ & Mean (P) & $\begin{array}{c}\text { One year seed } \\
\left(A_{1}\right)\end{array}$ & $\begin{array}{c}\text { Two year seed } \\
\left(\mathrm{A}_{2}\right)\end{array}$ & Mean $(P)$ \\
\hline Vacuum & 25.93 & 24.97 & $25.45^{\mathrm{ab}}$ & 18.75 & 18.25 & $18.50^{\mathrm{a}}$ \\
\hline 3 minutes & 26.55 & 25.05 & $25.80^{\mathrm{abc}}$ & 20.80 & 19.95 & $20.37^{a b}$ \\
\hline 6 minutes & 27.08 & 25.94 & $26.51^{\mathrm{bcd}}$ & 22.84 & 21.29 & $22.06^{\mathrm{b}}$ \\
\hline 9 minutes & 28.24 & 26.35 & $27.29^{\text {de }}$ & 25.30 & 23.99 & $24.64^{c}$ \\
\hline 12 minutes & 28.38 & 27.90 & $28.14^{\mathrm{e}}$ & 27.57 & 25.80 & $26.68^{c}$ \\
\hline 15 minutes & 26.55 & 27.50 & $27.02^{\text {cde }}$ & 27.62 & 25.60 & $26.61^{c}$ \\
\hline Control (untreated) & 25.56 & 24.37 & $24.96^{\mathrm{a}}$ & 18.52 & 18.36 & $18.44^{\mathrm{a}}$ \\
\hline Mean $(A)$ & $26.90^{\mathrm{A}}$ & $26.01^{B}$ & & $23.06^{\mathrm{A}}$ & $21.89^{\mathrm{B}}$ & \\
\hline \multirow[t]{3}{*}{$\mathrm{CD}(p=0.05)$} & (A) & 0.74 & & 1.15 & & \\
\hline & $(\mathrm{P})$ & 1.39 & & 2.16 & & \\
\hline & $(\mathrm{AxP})$ & NS & & NS & & \\
\hline
\end{tabular}


seed $(26.01 \mathrm{~cm})$.

Significant variations for seedling length were observed among all the plasma treatments. Thw longest seedling was, however, observed in the seed exposed to plasma for 12 minutes $(28.14 \mathrm{~cm})$, which was at par with 9 minutes $(27.29$ $\mathrm{cm})$ and 15 minutes $(27.02 \mathrm{~cm})$ treatment. The seed which was kept under vacuum and not exposed to plasma showed significantly smaller seedling $(25.45 \mathrm{~cm})$ compared to plasma treated seeds. While the smallest seedling $(24.96 \mathrm{~cm})$ was recorded in control seed where no vacuum and no plasma treatment were given.

Increase in the seedling length of Buckwheat seeds after the plasma treatment (Sera et al. 2010). The possible reason may be due to increase in the porosity that makes the seed coat porous, as a result seed rapidly imbibes water and the germination process is accelerated. Seeds with eroded seed coat would germinate faster than the healthy ones, accelerate water uptake resulting in increased seedling length (Spatenka et al., 2008).

Interaction effects of age of seed and plasma exposure time were statistically non-significant at $5 \%$ level of significance.

\subsection{Seedling weight}

The data presented in Table 2 indicated that the seedling dry weight of okra seed exposed to plasma treatments was significantly higher in one year old seed $(23.06 \mathrm{mg})$ than that of two year old seed (21.89 mg).

A significant improvement in seedling dry weight was observed due to plasma over control.. Higher seedling dry weight was, however, observed in the seed exposed to plasma for 12 minutes (26.68 $\mathrm{mg}$ ) which was at par with 15 minute (26.61 $\mathrm{mg}$ ) and 9 minutes $(24.64 \mathrm{mg}$ ) treatment. The seed which was kept under vacuum and not exposed to plasma showed significantly lower seedling dry weight (18.50 mg) compared to plasma treated seeds. The lowest seedling dry weight (18.44 mg) was observed in control seed where no treatment was given.

The amount of reserved food material mobilized during seedling growth, which ultimately contributed to difference in seedling dry weight (McDonald and Copeland, 2005).

The interaction effects of age of seed and plasma exposure time was found to be non-significant at $5 \%$ level of significance.

\subsection{Seedling vigour index-I}

The seedling vigour index (SVI-I) of okra seed exposed to plasma treatments was significantly higher in one year old seed (2486.16) than that of two year old seed (2244.96) are indicated in Table 3.

Significant influenced in the SVI-I as affected by exposure time of plasma to the seed. Higher SVI-I was, however, observed in the seed exposed to plasma for 12 minutes (2581.48), which was at par with 9 minutes (2486.33) treatment. The seed which was kept under vacuum and not exposed to plasma showed significantly lower SVI-I (2221.52) compared to plasma treated seeds. The lowest SVI-I (2176.25) was observed in control seed where no plasma treatment was given.

Plasma treated seeds have better permeability, which lead to enhanced seed germination resulting in increased seedling vigour index-I and II which is a result of germination percentage, seedling length and seedling dry weight (Azharonok et al. 2014).

Non-significant interaction effects due to age of seed and plasma exposure time were observed for SVI-I.

\subsection{Seedling vigour index II}

Observations recorded on Seedling Vigour Index-II (SVI-II)

Table 3: Effect of seed age and plasma treatment on seedling vigour index-I and seedling vigour index- II obtained from treated seeds in okra

\begin{tabular}{|c|c|c|c|c|c|c|}
\hline \multirow{2}{*}{$\begin{array}{l}\text { Plasma treatment } \\
\text { durations } \\
(\mathrm{P})\end{array}$} & \multicolumn{3}{|c|}{ Seedling vigour index-I } & \multicolumn{3}{|c|}{ Seedling vigour index-II } \\
\hline & $\begin{array}{c}\text { One year seed } \\
\left(A_{1}\right)\end{array}$ & $\begin{array}{c}\text { Two year seed } \\
\left(A_{2}\right)\end{array}$ & Mean (P) & $\begin{array}{c}\text { One year seed } \\
\left(A_{1}\right)\end{array}$ & $\begin{array}{c}\text { Two year seed } \\
\left(A_{2}\right)\end{array}$ & Mean $(P)$ \\
\hline Vacuum & 2353.00 & 2090.05 & $2221.52^{\mathrm{a}}$ & 1702.58 & 1531.60 & $1617.09^{a}$ \\
\hline 3 minutes & 2430.98 & 2128.51 & $2279.74^{\mathrm{ab}}$ & 1914.05 & 1693.56 & $1803.80^{\mathrm{ab}}$ \\
\hline 6 minutes & 2497.95 & 2272.23 & $2385.09^{b c}$ & 2110.85 & 1860.37 & $1985.61^{b}$ \\
\hline 9 minutes & 2641.42 & 2331.24 & $2486.33^{c d}$ & 2368.61 & 2120.84 & $2244.72^{c}$ \\
\hline 12 minutes & 2667.00 & 2495.95 & $2581.48^{d}$ & 2590.66 & 2308.05 & $2449.35^{c}$ \\
\hline 15 minutes & 2491.14 & 2365.90 & $2428.52^{b c}$ & 2597.50 & 2196.98 & $2397.24^{c}$ \\
\hline Control (untreated) & 2321.66 & 2030.85 & $2176.25^{\mathrm{a}}$ & 1686.02 & 1524.13 & $1605.07^{a}$ \\
\hline Mean (A) & $2486.16^{A}$ & $2244.96^{B}$ & & $2138.61^{A}$ & $1890.79^{B}$ & \\
\hline \multirow[t]{3}{*}{$\mathrm{CD}(p=0.05)$} & (A) & 81.20 & & 118.31 & & \\
\hline & $(P)$ & 115.92 & & 221.35 & & \\
\hline & $(\mathrm{AxP})$ & NS & & NS & & \\
\hline
\end{tabular}


revealed significantly higher in one year old seed (2138.61) than that of two year old seed (1890.79) is presented in Table 3.

Analysis of data revealed that exposure time of plasma to the seed significantly influenced the SVI-II. Higher SVI-II was, however, observed in the seed exposed to plasma for 12 minutes (2449.35) which was at par with 15 minute (2397.24) and 9 minutes (2244.72) treatment. The seed which was kept under vacuum and not exposed to plasma showed significantly lower SVI-II (1617.09) compared to plasma treated seeds. While the lowest SVI-II (1605.07) was recorded in control seed where no plasma treatment were given.

The interaction effects of age of seed and plasma exposure time was found to be non-significant at $5 \%$ level of significance.

\section{Conclusion}

Age of the seed greatly influenced the physiological quality of seed, emergence, growth, and yield and seed storage characteristics. Seeds treated with 12 minute plasma treatment proved its potential over other plasma treatments and control (untreated seeds) in both one year and two year old seeds. Hence, seed treatment with 12 minute plasma exposure can be used as a beneficial pre-sowing treatment to enhance the physiological, growth and yield in okra.

\section{Acknowledgement}

The authors are grateful to Dean, College of Horticulture, Dr YS Parmar University of Horticulture and Forestry, Solan, Himachal Pradesh, India for granting financial support to carry out the research work.

\section{References}

Abdul-Baki, A.A., Anderson, J.D., 1973. Vigour determination in soybean seed by multiple criteria. Crop Science 13, 630-633.

Ayoub, Z.E., Afrah, A.A., 2014. Effect of cultivar and sowing date on okra seed yield. Universal Journal of Applied Science 2(3), 64-67.

Azharonok, V., Filatova, I., Shedikova, O., Shik, A., 2014. Fungicidal and bactericidal effect of plasma and radiowave treatment on biological and medical materials. Plasma Science and Technology 12(2), 95-96.

Bormashenko, E., Grynyov, R., Bormashenko, Y., Drori, E., 2012. Cold radiofrequency plasma treatment modifies wettability and germination speed of plant seeds. Scientific Reports 2, 74.
Dell, Aquilla, A., 1987. Mean germination time as a monitor of the seed ageing. Plant Physiology Biochemistry 25, 761-768.

Dubinov, A.E., Lazarenko, E.M., Selemir, V.D., 2000. Effect of glow discharge air plasma on grain crops seed. IEEE Transactions on Plasma Science 28(1), 180-183.

Eke, K.A., Essien, B.A., Ogbu., J.U., 2008. Determination of optimum planting time of okra in the derived savannah. Proc. of the 42 nd Conf. of ASN at Abakaliki $17^{\text {th }}-23^{\text {rd }}$ Oct. 2008, 242-245.

Filatova, I., Azharnok, V., Gorodetskaya, E., Shedikova, O., Shik, A., 2010. Plasma radiowave stimulation of plant seeds germination and inactivation of pathogenic microorganisms. 2010. International Symposium on Plasma Chemistry conference.

Griesser, S.S., Prakas, S., Griesser, H.J., 2011. Plasma discharge treatment for improved germination of seeds and killing of fungal spores on seed coats. Final project report to the Australian Flora Foundation. Ian Wark Research Institute, University of South Australia, Mawson Lakes, SA 5095.

ISTA, 1985. ISTA (International Seed Testing Association). International rules for seed testing. Seed Science and Technology 13, 300-520.

Jiang, J., He, X., Li, L., Li, J., Shao, H., Xu, Q., Ye, R., Dong, Y., 2014. Effect of cold plasma treatment on seed germination and growth of wheat. Plasma Science and Technology 16(1), 54-57.

Maguire, J.D., 1962. Speed of germination-aid in selection and evaluation for seedling emergence and vigour. Crop Science 2, 176-177.

Schippers, R.R., 2000. African Indigenous Vegetable: an overview of the Cultivated Species. Chaltham U.K. National Resources Institute A.C.D.E.U. Technical Centre for Agro-culture and Rural Cooperation. 105-117.

Sera, B., Gajdova, I., Cernak, M., Gavril, B., Hnatiuc, E., Kovacik, D., Kriha, V., Slama, J., Sery, M., Spatenka, P., 2012. How various plasma sources may affect seed germination and growth. IEEE Plasma Science 39(7), 1365-1369.

Spatenka, P., Stranak, V., Sery, M., Tichy, M., Sera, B., 2008. Germination of Chenopodium album in response to microwave plasma treatment. Plasma Science and Technology 10(4), 506-510.

Tiamiyu, R.A., Ahmed, H.G., Muhammad, A.S., 2012. Effect of sources of organic manure on growth and yield of okra (Abelmoschus esculentus (L.) Moench) in Sokoto, Nigeria. Nigerian Journal of Basic and Applied Science 20(3), 213-216. 